\title{
AN INDICATION OF THE SUSTAINABLE DEVELOPMENT OF UKRAINE IN GLOBAL DIMENSIONS
}

\author{
Olena Kotykova ${ }^{1}$, Oleksii Albeshchenko² \\ Mykolayiv National Agrarian University, Ukraine
}

\begin{abstract}
The urgency of the research. In the early 90s of the last century, economists and scientists attributed Ukraine to the undisputed leaders due to the existing resource potential and predicted its rapid economic growth. Unfortunately, the predictions have not come true: over the last 25 years, Ukraine has lost its advantages on certain indicators. As for the positions, which have been saved, Ukraine should pay the unreasonably high price by the ecological and social conditions deterioration. Target setting. The question is how the other countries have coped with these problems. Moreover, in our opinion, the most valuable experience is the experience of post-socialist countries, which had the same problems as Ukraine had like adaptation problems to the market environment. Recent scientific researches and issues analysis. The most authoritative foreign researchers on the sustainable development problems are Donella H. Meadows, G. Brundtland, M. Ashby, N. Droste, K. Fiorella and others. The most authoritative researchers on the sustainable development problems in Ukraine are Mykhailo Zghurovskyi and his project performers. Uninvestigated parts of general matters defining. However, these researchers did not conduct the investigations of indication of the sustainable development of Ukraine in comparison with the countries of post-socialist camp. The research objective. The survey target is a comprehensive study of Ukraine in the global dimension of sustainable development index: the implementation of post-socialist countries ranking placement in the indices of economic, social and environmental dimension, the index of a sustainability, the index of economic measurement and index of harmonization, the components of quality of life and safety of life; the analysis of placement in these spaces in order to find patterns and distinctive features for a particular group of countries; setting of the countries' placement features in the above mentioned spaces and the comparison of groups with Ukraine. The statement of basic materials. The article deals with the author's research results about Ukraine's place in the sustainable development measuring global index. The valuation is performed by measuring metric indices of sustainable development in the space of three pillars (economic, environmental, and social) in the context of quality and safety of life. Conclusions. Performed the ranking of the post-socialist states' placement in the space of sustainable development index. The analysis of placement in these spaces in order to find patterns and distinctive features for a particular group of countries is made. Peculiarities of the placement in the abovementioned spaces are outlined, and the comparison of these groups with Ukraine is given.
\end{abstract}

Key words: sustainable development, quality of life, safety of life, social measurement index, economic measurement index, environmental measurement index.

\section{JEL Classification: P27, 057}

\section{Introduction}

In the early 90s of the last century, after the collapse of the Soviet Union, assessing the prospects for the future development of the countries, the former republics, economists and scientists (Heiets at al., 2003; Shulha, 2009; Petryshyna, 2014; Harvard University, 1998; Oxford University Press, 2000) attributed Ukraine to the undisputed leaders due to the existing resource potential and predicted its rapid economic growth. Unfortunately, the predictions have not come true: over the last 25 years, Ukraine has lost its advantages on certain indicators. As for the positions which have been saved, Ukraine should pay the unreasonably high price by the ecological and social conditions deterioration.

For example, among the countries of the former Soviet Union, Ukraine, along with Russia and Belarus, has still a negative rate of natural population growth. However, if the population decline in Belarus decreased from 41 to 11 thousand people from 2000 to 2012 (National Statistical Committee of the Republic of Belarus,

Corresponding author:

${ }^{1}$ Department of Business Economy, Mykolayiv National Agrarian University.

E-mail: kotikova@i.ua

${ }^{2}$ Department of Business Economy, Mykolayiv National Agrarian University.

E-mail: aalbeschenko@gmail.com 
2016), the population decline in Russia decreased from 958 to 4 thousand people (Russian Federation Federal State Statistics Service, 2016), but in Ukraine for this period of time the population decline decreased from 373 to 142 thousand people (State Statistics Service of Ukraine, 2015). And the reason for this population decline in Ukraine is a prevailing rate of mortality compared to birth.

This fact can have both objective and subjective preconditions. The objective preconditions are as follows: the country's low level of medical care and physical culture, poor quality of food and drinking water, no proper living conditions for life. The subjective preconditions are as follows: young people do not want to give birth, and not because they do not like children, but because they do not see their children's prospects. The question is how the other countries have coped with these problems. Moreover, in our opinion, the most valuable experience is the experience of post-socialist countries, which had the same problems as Ukraine had like problems of adaptation to the market environment, the formation of the political system, the establishment of private ownership, inefficient administrative management, irrational use of natural resources (use of energy-intensive technologies) and so on.

\section{Research objective and methodology}

The survey target is a comprehensive study of Ukraine in the global dimension of sustainable development index: the implementation of post-socialist countries ranking placement in the indices of economic, social and environmental dimension, the index of a sustainability, the index of economic measurement and index of harmonization, components of quality of life and safety of life; the analysis of the placement in these spaces in order to find patterns and distinctive features for a particular group of countries; setting of the countries' placement features in the abovementioned spaces, and the comparison of groups with Ukraine.

The assessment is carried out by the sustainability measuring metrics indices in the space of three components (economic, environmental, and social) in the context of quality and safety of life.

The abovementioned metrics is developed by the Institute for Applied Systems Analysis of the National Academy of Sciences of Ukraine and the Ministry of Education and Science of Ukraine. The methodology of evaluation and the analysis of sustainability, which is used in this study, include a model of sustainability, which is an interdisciplinary generalization of the models, which are known in the scientific, economic, and social fields of science and the technique of applying formal statistical methods and methods for expert evaluation to analyse the processes of sustainability. According to this methodology, the process of sustainability will be characterized by two main components: safety (Csl) and quality (Cql) of life (ICSU, 2013).

The index of sustainability is a quantitative measure of sustainability, taking into account the safety and quality of life. The quality of life component is an integrated assessment that considers together all the three dimensions of sustainability and, thus, reflects the inseparable relationship between the three spheres of society: economic, environmental, and social. The degree of sustainability harmonization reflects the balance between the economic, environmental, social, and institutional dimensions. The security of life component is an integrated assessment, which takes into account the total aggregate threats impact to the regions' sustainability, and the index of the region's vulnerability, in addition to the impact of the aggregate threats, reflects the degree of approximation of the region both to all threats in space, defined by Minkowski norm (ICSU, 2013).

\section{Research result}

According to the index of sustainability (Table 1), in 2007, Ukraine ranked the 72 nd place among all the world countries.

The index of sustainability in the country was 1,808 , which is close to the index in South Africa, Bosnia and Herzegovina, Sri Lanka, Guatemala, Tanzania.

Table 1

Indexes of sustainability, quality and safety of life in post-socialist countries for 2007

\begin{tabular}{|c|c|c|c|c|c|c|c|c|c|c|}
\hline \multirow[b]{2}{*}{$\begin{array}{l}\text { Country } \\
\text { code for } \\
\text { Alpha-2 }\end{array}$} & \multicolumn{2}{|c|}{ Index of sustainability } & \multicolumn{6}{|c|}{ Quality of life component } & \multicolumn{2}{|c|}{ Index of life safety } \\
\hline & 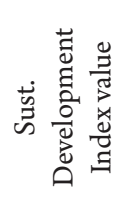 & 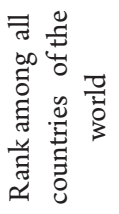 & 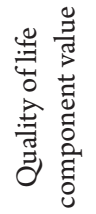 & 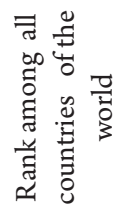 & 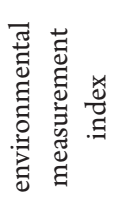 & 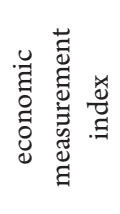 & 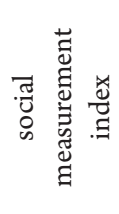 & 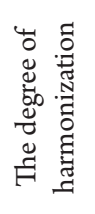 & 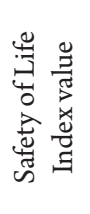 & 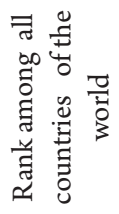 \\
\hline LT & 2,397 & 23 & 1,159 & 21 & 0,676 & 0,683 & 0,649 & 0,978 & 1,238 & 36 \\
\hline BG & 2,112 & 43 & 0,887 & 47 & 0,435 & 0,474 & 0,627 & 0,840 & 1,225 & 38 \\
\hline $\mathrm{CZ}$ & 2,206 & 37 & 0,959 & 40 & 0,345 & 0,623 & 0,693 & 0,735 & 1,247 & 34 \\
\hline $\mathrm{PL}$ & 1,949 & 55 & 0,788 & 59 & 0,306 & 0,425 & 0,634 & 0,711 & 1,162 & 57 \\
\hline HR & 2,300 & 32 & 1,035 & 32 & 0,690 & 0,402 & 0,699 & 0,773 & 1,265 & 32 \\
\hline SK & 2,324 & 28 & 1,038 & 31 & 0,513 & 0,630 & 0,656 & 0,897 & 1,285 & 26 \\
\hline
\end{tabular}




\begin{tabular}{|c|c|c|c|c|c|c|c|c|c|c|}
\hline EE & \multicolumn{10}{|c|}{ End of Table } \\
\hline LV & 2,531 & 19 & 1,246 & 16 & 0,659 & 0,820 & 0,679 & 0,900 & 1,285 & 26 \\
\hline RO & 2,412 & 22 & 1,145 & 23 & 0,712 & 0,605 & 0,667 & 0,934 & 1,267 & 30 \\
\hline MD & 1,941 & 57 & 0,815 & 55 & 0,335 & 0,474 & 0,602 & 0,772 & 1,126 & 70 \\
\hline UA & $\mathbf{1 , 8 0 8}$ & $\mathbf{7 2}$ & $\mathbf{0 , 6 5 9}$ & $\mathbf{7 5}$ & $\mathbf{0 , 2 9 9}$ & $\mathbf{0 , 3 3 1}$ & $\mathbf{0 , 5 1 1}$ & $\mathbf{0 , 7 5 9}$ & $\mathbf{1 , 1 4 9}$ & $\mathbf{6 4}$ \\
\hline GE & 1,911 & 59 & 0,832 & 54 & 0,477 & 0,514 & 0,450 & 0,945 & 1,080 & 88 \\
\hline AM & 2,237 & 35 & 1,050 & 29 & 0,761 & 0,344 & 0,712 & 0,702 & 1,188 & 48 \\
\hline RU & 2,142 & 40 & 0,795 & 58 & 0,604 & 0,337 & 0,435 & 0,764 & 1,347 & 18 \\
\hline KG & 1,703 & 85 & 0,611 & 83 & 0,392 & 0,351 & 0,315 & 0,911 & 1,092 & 85 \\
\hline AZ & 1,820 & 69 & 0,621 & 78 & 0,315 & 0,369 & 0,392 & 0,911 & 1,199 & 44 \\
\hline UZ & 1,516 & 101 & 0,412 & 104 & 0,119 & 0,279 & 0,316 & 0,655 & 1,104 & 81 \\
\hline KZ & 1,896 & 60 & 0,699 & 69 & 0,397 & 0,427 & 0,387 & 0,958 & 1,197 & 45 \\
\hline TJ & 1,555 & 99 & 0,437 & 101 & 0,177 & 0,288 & 0,291 & 0,793 & 1,118 & 75 \\
\hline
\end{tabular}

Source: made by the author (Global analysis of the quality and safety of human life, 2016)

Among the group of post-socialist countries, Ukraine took the 16th place, ahead of the Kyrgyz Republic, Tajikistan, and Uzbekistan.

According to the quality of life component value in 2007, Ukraine ranked the 75th place in the world, giving the way to such countries as the Republic of Lithuania, Bulgaria, Poland, Croatia, Estonia, Latvia, Czech Republic, Slovakia, Romania by the index. The worst value was recorded in the index of economic and environmental dimensions, where Ukraine was ahead of only two countries - Uzbekistan and Tajikistan.

According to the safety of life index value in 2007, Ukraine ranked the 64th place in the world and the 13th place among the post-socialist countries, ahead of Romania, Georgia, Kyrgyzstan, Uzbekistan, and Tajikistan.

Then, in 2007, Ukraine was among five outsiders in terms of sustainability and quality of life component for all indicators except the social dimension index (Fig. 1).

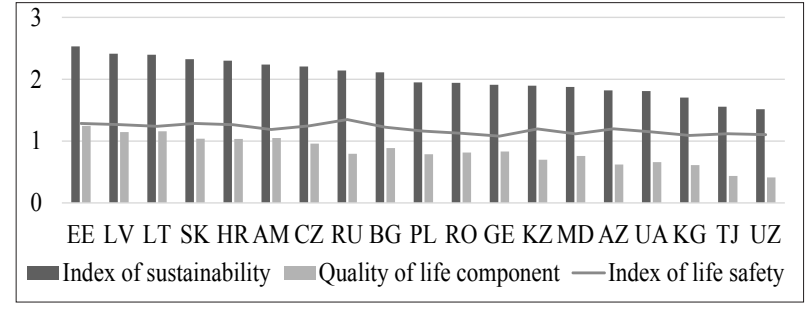

Fig. 1. Indexes of sustainability, quality, and safety of human life rated in post-socialist countries for 2007

Source: made by the author (Global analysis of the quality and safety of human life, 2016)

In 2010, Ukraine's place in the global ranking on the index of sustainability increased by three points. Among the group of post-socialist countries, Ukraine ranked just the 16th place, and like last year, it was at the top of five outsiders in all indicators except social dimension and life safety indices (Table 2).

Table 2

Indexes of sustainability, quality, and safety of life in post-socialist countries for 2010

\begin{tabular}{|c|c|c|c|c|c|c|c|c|c|c|}
\hline \multirow[b]{2}{*}{$\begin{array}{l}\text { Country } \\
\text { code for } \\
\text { Alpha-2 }\end{array}$} & \multicolumn{2}{|c|}{ Index of sustainability } & \multicolumn{6}{|c|}{ Quality of life component } & \multicolumn{2}{|c|}{ Index of life safety } \\
\hline & 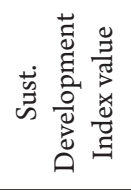 & 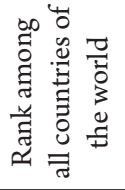 & 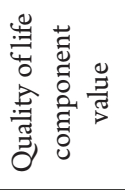 & 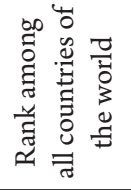 & 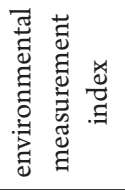 & 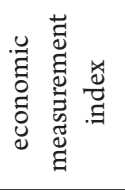 & 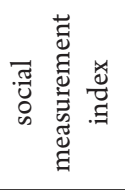 & 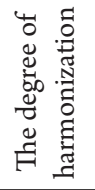 & 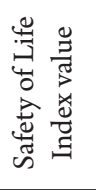 & 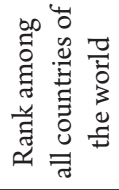 \\
\hline LT & 2,350 & 31 & 1,125 & 26 & 0,646 & 0,615 & 0,686 & 0,955 & 1,225 & 39 \\
\hline $\mathrm{BG}$ & 2,129 & 45 & 0,932 & 47 & 0,525 & 0,472 & 0,617 & 0,892 & 1,197 & 46 \\
\hline $\mathrm{CZ}$ & 2,425 & 22 & 1,214 & 21 & 0,709 & 0,669 & 0,725 & 0,967 & 1,211 & 41 \\
\hline PL & 2,235 & 38 & 1,009 & 37 & 0,538 & 0,535 & 0,675 & 0,888 & 1,226 & 38 \\
\hline $\mathrm{HR}$ & 2,268 & 34 & 1,000 & 38 & 0,653 & 0,435 & 0,645 & 0,827 & 1,267 & 29 \\
\hline SK & 2,408 & 23 & 1,176 & 23 & 0,757 & 0,611 & 0,669 & 0,912 & 1,232 & 33 \\
\hline $\mathrm{EE}$ & 2,392 & 25 & 1,121 & 27 & 0,553 & 0,703 & 0,686 & 0,896 & 1,271 & 27 \\
\hline LV & 2,325 & 33 & 1,095 & 30 & 0,724 & 0,526 & 0,646 & 0,872 & 1,230 & 34 \\
\hline RO & 2,091 & 50 & 0,992 & 40 & 0,620 & 0,510 & 0,589 & 0,920 & 1,099 & 84 \\
\hline $\mathrm{MD}$ & 1,713 & 83 & 0,619 & 83 & 0,445 & 0,146 & 0,481 & 0,602 & 1,094 & 87 \\
\hline UA & 1,866 & 69 & 0,714 & 73 & 0,432 & 0,294 & 0,511 & 0,786 & 1,152 & 65 \\
\hline GE & 2,015 & 56 & 0,876 & 49 & 0,549 & 0,535 & 0,432 & 0,897 & 1,139 & 67 \\
\hline $\mathrm{AM}$ & 2,051 & 52 & 0,860 & 52 & 0,493 & 0,325 & 0,671 & 0,723 & 1,191 & 48 \\
\hline RU & 2,093 & 49 & 0,740 & 69 & 0,497 & 0,358 & 0,427 & 0,868 & 1,353 & 15 \\
\hline
\end{tabular}




\begin{tabular}{|c|c|c|c|c|c|c|c|c|c|c|}
\hline KG & 1,774 & 75 & 0,653 & 78 & 0,463 & 0,359 & 0,308 & 0,830 & 1,121 & 77 \\
\hline AZ & 1,961 & 60 & 0,761 & 65 & 0,451 & 0,474 & 0,394 & 0,923 & 1,199 & 44 \\
\hline UZ & 2,636 & 13 & 1,268 & 16 & 0,546 & 0,851 & 0,801 & 0,819 & 1,368 & 13 \\
\hline KZ & 1,907 & 64 & 0,720 & 72 & 0,413 & 0,464 & 0,370 & 0,907 & 1,187 & 50 \\
\hline TJ & 1,562 & 97 & 0,493 & 92 & 0,295 & 0,264 & 0,296 & 0,948 & 1,069 & 94 \\
\hline
\end{tabular}

Source: made by the author (Global analysis of the quality and safety of human life, 2016)

In 2011-2012, Ukraine's position in the global dimension according to the sustainability index remained unchanged (Table 3 ).

Among the post-socialist countries, Ukraine climbs one step in the ranking index of environmental measurement with simultaneous fall in the unit of the rating value according to the index of the economic dimension. During this period in the overall ranking, Ukraine's position improved significantly according to the social dimension indicator, but the index value decreased. In the period of 2010-2011, Ukraine closed the top five outsiders rating among the post-socialist countries.

In 2013, according to the global rating, Ukraine lost five positions, but the sustainability index value increased from 1,836 to 1,865 (Table 4).

Thus, Ukraine was among top five outsiders according to the quality of life components, namely, the economic dimension index and the degree of harmonization (Fig. 2).

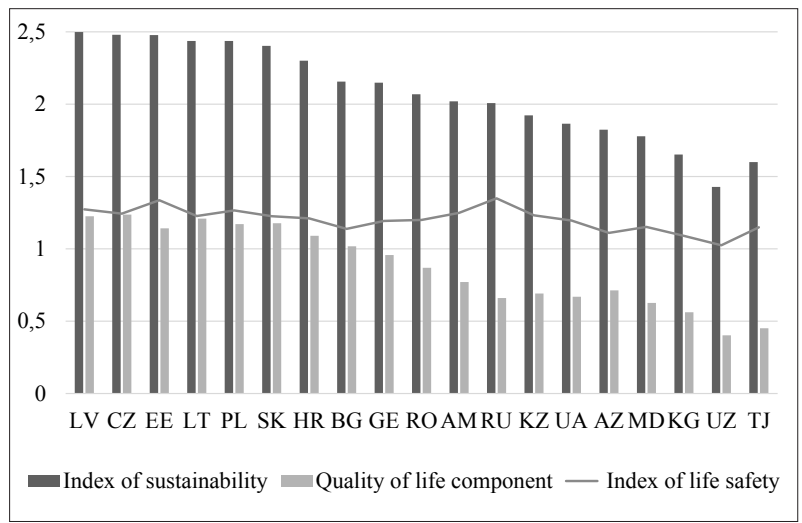

Fig. 2. Indexes of sustainability, quality, and safety of life rated in post-socialist countries for 2013

Source: grouped by the author (Global analysis of the quality and safety of human life, 2016)

From 2005 to 2013, Ukraine's position in the rating table on sustainability decreased from the 47 th place in 2005 to the 74th place in 2013 (Fig. 3).

Table 3

Indexes of sustainability, quality, and safety of life in post-socialist countries for 2011-2012

\begin{tabular}{|c|c|c|c|c|c|c|c|c|c|c|}
\hline \multirow[b]{2}{*}{$\begin{array}{l}\text { Country } \\
\text { code for } \\
\text { Alpha-2 }\end{array}$} & \multicolumn{2}{|c|}{ Index of sustainability } & \multicolumn{6}{|c|}{ Quality of life component } & \multicolumn{2}{|c|}{ Index of life safety } \\
\hline & 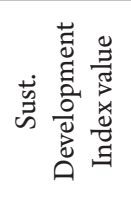 & 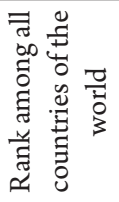 & 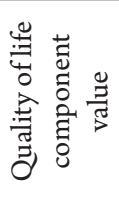 & 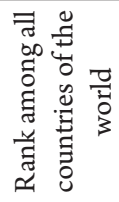 & 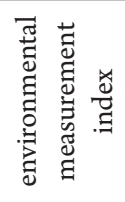 & 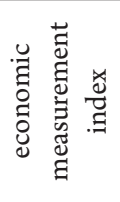 & 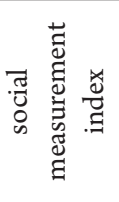 & 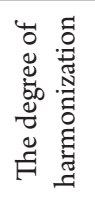 & 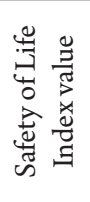 & 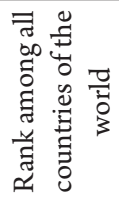 \\
\hline $\mathrm{LT}$ & 2,328 & 33 & 1,118 & 29 & 0,647 & 0,630 & 0,659 & 0,982 & 1,210 & 43 \\
\hline BG & 2,101 & 47 & 0,965 & 44 & 0,527 & 0,503 & 0,642 & 0,892 & 1,136 & 70 \\
\hline $\mathrm{CZ}$ & 2,425 & 22 & 1,206 & 18 & 0,709 & 0,660 & 0,720 & 0,962 & 1,220 & 38 \\
\hline $\mathrm{PL}$ & 2,282 & 35 & 1,039 & 37 & 0,539 & 0,571 & 0,690 & 0,892 & 1,243 & 31 \\
\hline HR & 2,244 & 39 & 1,003 & 39 & 0,654 & 0,437 & 0,647 & 0,828 & 1,241 & 32 \\
\hline SK & 2,396 & 24 & 1,161 & 23 & 0,757 & 0,585 & 0,670 & 0,895 & 1,235 & 34 \\
\hline $\mathrm{EE}$ & 2,400 & 23 & 1,131 & 26 & 0,554 & 0,715 & 0,690 & 0,892 & 1,269 & 28 \\
\hline LV & 2,336 & 32 & 1,098 & 31 & 0,725 & 0,517 & 0,661 & 0,864 & 1,238 & 33 \\
\hline RO & 2,149 & 44 & 1,003 & 39 & 0,621 & 0,508 & 0,610 & 0,912 & 1,145 & 66 \\
\hline $\mathrm{MD}$ & 1,790 & 74 & 0,695 & 73 & 0,447 & 0,337 & 0,421 & 0,884 & 1,094 & 88 \\
\hline UA & 1,836 & 69 & 0,686 & 74 & 0,434 & 0,255 & 0,500 & 0,745 & 1,149 & 64 \\
\hline GE & 2,032 & 54 & 0,884 & 49 & 0,550 & 0,517 & 0,464 & 0,930 & 1,147 & 65 \\
\hline $\mathrm{AM}$ & 2,029 & 55 & 0,805 & 58 & 0,481 & 0,490 & 0,423 & 0,937 & 1,224 & 36 \\
\hline RU & 0,296 & 50 & 0,743 & 67 & 0,498 & 0,359 & 0,429 & 0,868 & 1,353 & 15 \\
\hline KG & 1,755 & 77 & 0,660 & 77 & 0,465 & 0,339 & 0,339 & 0,845 & 1,095 & 87 \\
\hline $\mathrm{AZ}$ & 1,913 & 64 & 0,792 & 62 & 0,452 & 0,470 & 0,449 & 0,980 & 1,121 & 73 \\
\hline UZ & 1,438 & 103 & 0,390 & 100 & 0,162 & 0,204 & 0,310 & 0,730 & 1,048 & 100 \\
\hline $\mathrm{KZ}$ & 1,962 & 60 & 0,741 & 68 & 0,415 & 0,466 & 0,403 & 0,936 & 1,221 & 37 \\
\hline $\mathrm{TJ}$ & 1,624 & 89 & 0,473 & 91 & 0,296 & 0,256 & 0,266 & 0,938 & 1,151 & 62 \\
\hline
\end{tabular}

Source: made by the author (Global analysis of the quality and safety of human life, 2016) 
Table 4

Indexes of sustainability, quality, and safety of life in post-socialist countries for 2013

\begin{tabular}{|c|c|c|c|c|c|c|c|c|c|c|}
\hline \multirow[b]{2}{*}{$\begin{array}{l}\text { Country } \\
\text { code for } \\
\text { Alpha-2 }\end{array}$} & \multicolumn{2}{|c|}{ Index of sustainability } & \multicolumn{6}{|c|}{ Quality of life component } & \multicolumn{2}{|c|}{ Index of life safety } \\
\hline & 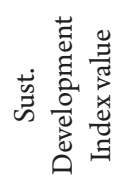 & 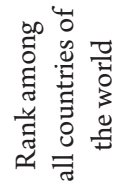 & 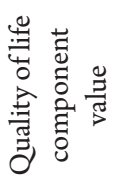 & 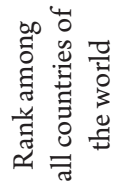 & 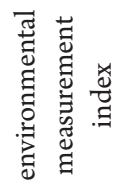 & 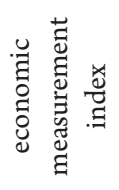 & 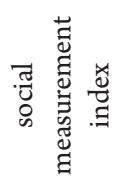 & 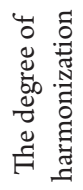 & 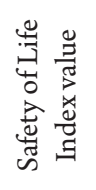 & 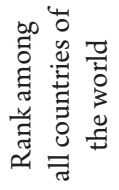 \\
\hline LT & 2,437 & 29 & 1,209 & 25 & 0,772 & 0,642 & 0,674 & 0,917 & 1,227 & 42 \\
\hline BG & 2,156 & 47 & 1,018 & 43 & 0,558 & 0,540 & 0,659 & 0,907 & 1,138 & 80 \\
\hline $\mathrm{CZ}$ & 2,480 & 23 & 1,237 & 21 & 0,758 & 0,648 & 0,732 & 0,931 & 1,243 & 37 \\
\hline $\mathrm{PL}$ & 2,437 & 29 & 1,171 & 29 & 0,732 & 0,591 & 0,698 & 0,907 & 1,266 & 33 \\
\hline HR & 2,301 & 40 & 1,090 & 35 & 0,746 & 0,435 & 0,665 & 0,780 & 1,211 & 46 \\
\hline SK & 2,403 & 32 & 1,177 & 27 & 0,792 & 0,547 & 0,678 & 0,845 & 1,226 & 43 \\
\hline $\mathrm{EE}$ & 2,478 & 24 & 1,142 & 31 & 0,552 & 0,709 & 0,708 & 0,885 & 1,336 & 18 \\
\hline LV & 2,499 & 21 & 1,225 & 22 & 0,851 & 0,559 & 0,682 & 0,822 & 1,273 & 30 \\
\hline RO & 2,069 & 54 & 0,869 & 54 & 0,350 & 0,503 & 0,616 & 0,771 & 1,200 & 50 \\
\hline MD & 1,778 & 90 & 0,626 & 91 & 0,278 & 0,346 & 0,442 & 0,805 & 1,152 & 66 \\
\hline UA & 1,865 & 74 & 0,669 & 85 & 0,303 & 0,299 & 0,517 & 0,721 & 1,196 & 51 \\
\hline GE & 2,149 & 49 & 0,957 & 49 & 0,573 & 0,585 & 0,494 & 0,924 & 1,193 & 53 \\
\hline $\mathrm{AM}$ & 2,020 & 56 & 0,771 & 65 & 0,330 & 0,536 & 0,444 & 0,800 & 1,249 & 35 \\
\hline RU & 2,008 & 57 & 0,660 & 86 & 0,283 & 0,357 & 0,447 & 0,778 & 1,349 & 16 \\
\hline KG & 1,652 & 98 & 0,562 & 99 & 0,303 & 0,317 & 0,351 & 0,935 & 1,090 & 96 \\
\hline $\mathrm{AZ}$ & 1,824 & 84 & 0,713 & 74 & 0,236 & 0,491 & 0,461 & 0,706 & 1,110 & 89 \\
\hline $\mathrm{UZ}$ & 1,428 & 112 & 0,402 & 111 & 0,088 & 0,211 & 0,331 & 0,537 & 1,025 & 111 \\
\hline $\mathrm{KZ}$ & 1,923 & 68 & 0,691 & 81 & 0,094 & 0,534 & 0,429 & 0,488 & 1,232 & 40 \\
\hline $\mathrm{TJ}$ & 1,600 & 104 & 0,451 & 107 & 0,162 & 0,305 & 0,289 & 0,740 & 1,149 & 70 \\
\hline
\end{tabular}

Source: grouped by the author (Global analysis of the quality and safety of human life, 2016)

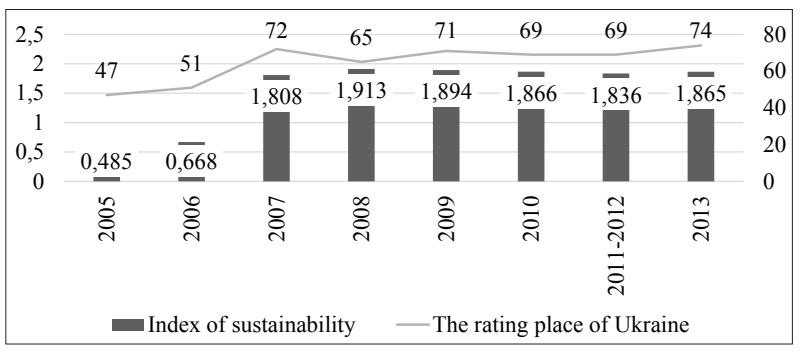

Fig. 3. Dynamics of Ukraine's rating place

in the global dimension according to the index of sustainability (2005-2013)

Source: grouped by the author (Global analysis of the quality and safety of human life, 2016)

Though the value of the indicator increased to 2008 , the rating fell. This situation is explained by two factors: firstly, to 2007 the calculation method of sustainability index was somewhat different, but this factor does not affect the rating of the country's place in the world; secondly, in other countries the increase of sustainability index is well ahead of the pace in Ukraine, which allows them to climb the rating table.

Ukraine has reached a rather high level according to the components of inequality between countries and people and the limit of water use compared to other post-socialist countries. According to these indicators, the country takes the third place. Ukraine has average values according to the components of energy security and child mortality - the 7th and the 9th places in the ranking, respectively. The worst situation in the country, according to the components of quality of life, is with the indicators of corruption level and the level of global diseases. According to these indicators, Ukraine ranked the 16th and the 15th places respectively, and it is slightly ahead of the Kyrgyz Republic, Tajikistan, and Uzbekistan (Fig. 4).

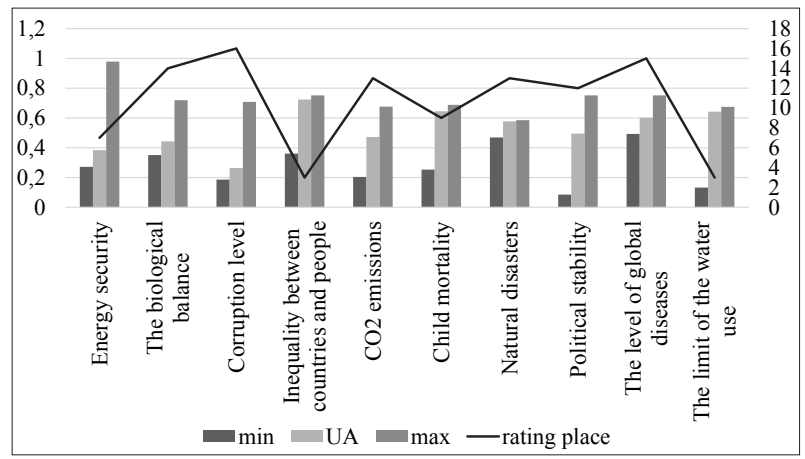

Fig. 4. The rating place of Ukraine among the post-socialist countries according to the safety of life components

Source: grouped by the author (Global analysis of the quality and safety of human life, 2016) 


\section{Conclusion}

From the abovementioned, we can conclude the following. Ukraine, which in the late 80 s had one of the best starting points for the countries of the group, was constantly losing the advantages of its economy, basic science, advanced education, quality of human capital. Thus, according to the World Data Center for Geoinformatics and Sustainability (WDC-IASAFORESIGHT, 2016), during the years of independence, the Ukraine's economic downturn was at around $60 \%$ of the achieved production in 1991, which is comparable to the losses during the Second World War of the German, Japan, and the USSR economy. However, the economies of these countries reached the pre-war level indicators for about seven years, but the economy of Ukraine during the years of its independence fell from the 8th-10th places in Europe in 1991 to almost the last one.

The fact that worries is that Ukraine almost according to all defining indices, indicators, and sustainability indicators is significantly inferiors not only to the world leaders but to the most post-socialist countries, which were taken for comparison. During the study period, the Republic of Lithuania, Estonia, and Latvia (except 2010) kept a stable position of five post-socialist countries with the highest rating according to the index of sustainability. Instead, Ukraine (except 2013) according to the index of sustainability was one of the five outsiders of the group of countries with the Kyrgyz Republic, Tajikistan, and Uzbekistan (except 2010).

To determine the future orientations of Ukraine's development, both threats and possibilities should be considered. Ukraine's objective advantage is its favourable geographical and geopolitical position. As for the labour potential availability and use, Ukraine has significant advantages compared to other postSoviet countries - 42 million of the highly educated population (according to the UNO the education enrolment rate in Ukraine is 94\%). Being located on the shores of the Black and Azov seas, with a powerful gas and transport network in transit, Ukraine is a "Silk Road" for energy, cultural, and commercial exchange between East and West. As for its territory, Ukraine ranks the second place in Europe (over 600 thousand square kilometres), which determines the optimal size for the accelerated development of the area. The availability of the significant land resource potential (a fertile soil and its large area), an impressive diversity of soil and climatic conditions provide considerable advantages in the development of agrarian and food sectors of the country's economy. A high capacity by the bioclimatic potential for the people's life creates the necessary conditions for the growth of the quality of life social component of the country's population.

It is important for Ukraine to avoid fundamental mistakes. The risk is that much easier to prefer the successful "template", particularly a visually attractive economic development, without a united, holistic model of environmental and social spheres. Moreover, the implementation of sustainability concept does not guarantee the rapid growth of human welfare but will require hard work and consolidated efforts of politicians, managers, scientists, and all progressive people of Ukraine. Another condition for sustainability is the political will of the state's senior management to go a hard, but the only correct way. The crisis of Ukraine's national ideology and strategy of development, which is delayed, can play a positive role. This is the role of the "blank page", which gives Ukraine a chance to use the best of the acquired by the international community. This is the experience of a harmonious and sustainable development of the society, in which people's welfare, the environment, natural resources, and human capital embodied in the achievements of science, education, advanced technologies, and high moral values are the inseparable, equal, and mutually complementary categories, the ones that enrich each other.

Based on the results of the research and relying on the expert opinions of such international organizations and scientific and educational centres as the International Council for Science (ICS, 2011), UNIDO (UNIDO United Nations Industrial Development Organization, 2001) and the world's leading universities and research universities such as Oxford University, NISTEP (National Institute of Science and Technology Policy, Japan), Institute for Critical Technology and Applied Science (Virginia Tech), Wageningen UR (Research University, the Netherlands), it should be noted that for Ukraine the solution of the defined socio-economic and environmental problems involves changing the technological structure of the country's development. These technologies include those associated with alternative energy (in the ranking of the world's countries, according to the share of renewable energy, Ukraine is among ten countries-outsiders), biotechnology, information and communication technology, the study of life and new materials. The priority areas for the development of these technologies should be the following: information and communication; electronics; the study of life; health care, medical care, and social security (Ukraine ranks the 61st place in the world according to the global diseases indicator); agriculture, forestry, fishery and food; energy and resources; environment; nanotechnology and new materials; production and industrial infrastructure; social infrastructure; social technologies.

We are deeply convinced (and this is confirmed by the results of the study) that corruption is one of the major obstacles to the economic growth and social development of Ukraine's society. Corruption is one of the most pressing social problems, a phenomenon, which is formed as a method of government officials, politicians, and public officials, established for a considerable period of time on the level of mentality. However, to solve this problem without the political 
will of those who are in power is impossible. So, the immediate measures should be directed to: extensive economy liberalization (the cancellation of the most matching bodies in the economy and society, the reduction in the number of employees in these units); strengthening of responsibility for the avoiding of public reporting on profits and expenditures made by persons connected with the public service, for their close family members, or persons treated like them; tax reform and liberalization of the tax system should be carried out simultaneously with the increasing responsibility of individuals and entities for the violation of tax legislation; the transition to a civilized land market with the simultaneous solving of problems on the creation of local financial and credit system and insurance system for AIC, including land bank, small and medium farmers, agribusiness transition to higher technological modes.

\section{References:}

Zghurovskyi, M. (2016). Foresight and construction of the strategies of socio-economic development of Ukraine in the mid-term (up to 2020) and long-term (up to 2030) time horizons, Ukraine: NTUU "Igor Sikorsky KPI", Publ. house "Polytechnica". Retrieved from: http://wdc.org.ua/sites/default/files/WDC-IASA-FORESIGHT2016-EN.pdf

Shulha, M. (2009). Geopolitical attitudes and security of Ukraine. According to sociologists, Ukraine: Typography "Biznespolihraf".

Zghurovskyi, M. (2014). Global analysis of the quality and safety of human life. Retrieved from: http://wdc.org.ua/ $\mathrm{uk} /$ services/country-profiles-visualization (accessed 17/09/2017)

National Statistical Committee of the Republic of Belarus 2016 Demography. Retrieved from: http://www.belstat.gov.by/ofitsialnaya-statistika/solialnaya-sfera/demografiya_2/g/obschie-koeffitsientysmertnosti-naseleniya-po-oblastyam-i-g-minsku/ (accessed 17/09/2017)

Heiets, V., Aleksandrova, V., Artomova, T., Bazhal, Yu., Baranovskyi, O., Blyzniuk, V., Bolkhovitinova, O., Brydun, Ye., Vakhnenko, T., Holikov V. (2003). Ukraine's economy: strategy and long-term development policy, NAS of Ukraine : Feniks.

Federal State Statistics Service of Russian Federation 2016. Demography. Retrieved from: http://www.gks.ru/bgd/ regl/b13_13/IssWWW.exe/Stg/d4/26-05.htm (accessed 17/09/2017)

Petryshyna, N. (2014). Problems of economic transformation in Ukraine. Retrieved from: http://irbis-nbuv.gov.ua/ cgi-bin/irbis_nbuv/cgiirbis_64.exe?C21COM=2\&I21DBN=UJRN\&P21DBN=UJRN\&IMAGE_FILE_

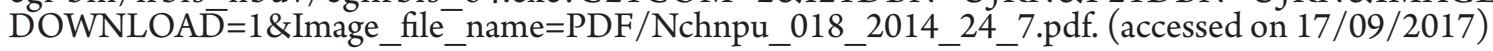

State Statistics Service of Ukraine 2014 Statistical Yearbook of Ukraine. Retrieved from: http: / /www.ukrstat.gov.ua/ (accessed 17/09/2017)

Zghurovskyi, M. (2016). Foresight and construction of the strategies of socio-economic development of Ukraine in the mid-term (up to 2020) and long-term (up to 2030) time horizons, Ukraine: NTUU «Igor Sikorsky KPI», Publ. house «Polytechnica». Retrieved from: http://wdc.org.ua/sites/default/files/WDC-IASA-FORESIGHT2016-EN.pdf

Ben, M. (2001). Technology foresight in a rapidly globalizing economy, University of Sussex: Brighton. Retrieved from: http://www. unido.org/fileadmin/import/12224_01Martinslide. pdf.

ICSU (2011). Strategic Plan II, 2012-2017 (including a summary of progress made in implementing the Strategic Plan I, 2006-2011), Paris: ICSU.

Lubomyr, A. (1998). Ukraine in the World, Harvard: Harvard University.

Sharon, L., Zviglyanich, V. (2000). Ukraine. The Search for a National Identity, Oxford: Oxford University Press. 